\title{
Contingent Valuation of Woodland-Owner Private Amenities in Spain, Portugal, and California
}

\author{
Pablo Campos, ${ }^{1}$ Jose L. Oviedo, ${ }^{2}$ Alejandro Caparrós, ${ }^{3}$ Lynn Huntsinger, ${ }^{4}$ and Inocencio Coelho ${ }^{5}$
}

Authors are ${ }^{1}$ Research Professor, ${ }^{2}$ Assistant Research Professor, and ${ }^{3}$ Associate Research Professor, Institute for Public Goods and Policies (IPP), Spanish National Research Council (CSIC), 28037 Madrid, Spain; ${ }^{4}$ Professor, Department of Environmental, Science, Policy and Management (ESPM), University of California, Berkeley, CA 94720, USA; and ${ }^{5}$ Senior Researcher, National Institute of Biological Resources, 2005-058 Santarém, Portugal.

\begin{abstract}
Most of the Mediterranean woodlands in Spain, Portugal, and California are managed as agrosilvopastoral enterprises, producing some combination of livestock, wood, cork products, and crops, as well as wildlife habitat and diverse environmental services. Private amenity benefits to landowners have been suggested as an explanation for high land prices and the persistence of such rangeland enterprises despite apparently marginal cash returns. In this study, private amenity values are estimated using a contingent valuation technique in surveys of private woodland owners as part of five case studies, using a design developed to separate landowner amenity income and capital values. Nonindustrial private landowners were asked about the maximum amount of money that they were willing to give up (to pay) before selling their property to invest in more commercially profitable assets, and the proportion of the market price of their woodland that they think is explained by privately consumed amenities. Amenity values were found to be relevant because, in all cases, landowners were willing to $\mathrm{pay}^{>} € 120 \cdot \mathrm{ha}^{-1} \cdot \mathrm{yr}^{-1}$, at 2002 prices, and attributed $>30 \%$ of land market price to amenities. These values represent an amenity profitability rate $>2 \%$ in all case studies. The data analysis shows some similarities, but mostly divergences, in the different land-simulated and amenity-simulated markets.
\end{abstract}

\section{Resumen}

La mayor parte de los bosques Mediterráneos en España, Portugal y California se gestionan como empresas agro-silvopastorales con el fin de producir ganado, madera y corcho y/o cultivos agrícolas, así como hábitat para la fauna salvaje y diversos servicios ambientales. Los beneficios ambientales privados de los propietarios de la tierra han sido sugeridos como un factor importante a la hora de explicar tanto los precios de la tierra como la persistencia de estas empresas agro-silvo-pastorales, a pesar de los aparentemente escasos beneficios monetarios obtenidos por los propietarios. En este trabajo se presenta una valoración de servicios ambientales privados de bosques a través de la técnica de la valoración contingente aplicada a una encuesta de propietarios privados de bosques mediterráneos en cinco casos de estudios, empleando un diseño que permite obtener de manera separada los valores de renta y capital de estos servicios ambientales privados. A los propietarios se les preguntó la máxima cantidad de dinero que estaban dispuestos a dejar de ganar (a pagar) antes de vender su tierra para invertir en otros activos comercialmente más rentables, y la proporción del precio de su finca que piensan que viene explicado por los servicios ambientales privados. Estos valores son relevantes en todos los casos, en la medida en que los propietarios estaban dispuestos a pagar $>120 € \cdot \mathrm{ha}^{-1} \cdot$ año $^{-1}$, a precios de 2002 , y atribuyeron $>30 \%$ del precio de la tierra a los servicios ambientales. Estos valores representan una tasa de rentabilidad ambiental $>2 \%$ en todos los casos de estudio. El análisis de los datos muestra algunas similitudes pero sobre todo divergencias entre los distintos mercados simulados de la tierra y de los servicios ambientales.

Key Words: agroforestry systems, environmental economics, environmental services, Mediterranean woodlands, private ownership, stated preferences

\section{INTRODUCTION}

Research was supported by the MEDMONT project (MEDMONT-QLRT-1999-31031) from the European Commission, and by the Integrated Hardwood Range Management Program of the University of California. J.L.O. was funded by Grant OT-03-003 from the Instituto Nacional de Investigación y Tecnología Agraria y Alimentaria (INIA) of Spain and the Rustici Chair in Rangeland Management at the University of California, Berkeley.

Correspondence: Dr Pablo Campos, Institute for Public Goods and Policies (IPP), Spanish National Research Council (CSIC), Albasanz 26-28, 3E3, 28037 Madrid, Spain. Email: pablo.campos@cchs.csic.es

Manuscript received 29 July 2008; manuscript accepted 5 March 2009.
The majority of Mediterranean woodlands in Spain, Portugal, and California are managed as privately owned agrosilvopastoral enterprises, producing some combination of livestock, wood, cork products, and crops, as well as wildlife habitat and diverse environmental services. It can be posited that privateamenity benefits have an important role in the way these ecosystems are managed because they have been shown to partly explain land market prices and because ranchers persist despite apparently marginal cash returns from their enterprises (Smith and Martin 1972; Torell et al. 2001). These woodlands are generally considered at risk of conversion to alternative 
land uses that provide far fewer environmental services to society. Understanding the motivations that underlie landowner decisions is crucial to efforts to increase the sustainability of these ecosystems. This study examines the characterization of rangeland landowners as "lifestyle consumers" by examining empirically the economic value of rangeland amenities to private landowners.

\section{The Concept of Private Amenities as a Landowner Income}

Traditionally, market prices for agricultural land are explained by the discounted, expected, commercial net returns from the land. However, in the past $40 \mathrm{yr}$, inconsistencies have been observed between land prices and commercial net returns from private rangelands: Although the former are increasing, the latter are decreasing in real terms (Martin and Jefferies 1966; Torell et al. 2001). It seems that there are some missing, unpriced returns to landowners that justify these land price increases and that need to be identified and measured to understand the woodland market and landowner behavior as consistent with capital investment theory. Although tax sheltering, expectation of land price increases, and speculative motivations have been identified as potential explanations for high land prices and landowner persistence in ranching, these have been found to be only weakly explanatory by some authors (Martin and Jefferies 1966; Pope 1987). Smith and Martin (1972) also consider "land fundamentalism," that landowners keep their land investment because they do not know other ways of making a living or investing. This should apply mostly to those who have owned land for a long time but cannot explain why current buyers choose to pay a premium price for the land (Torell et al. 2001).

In this article, we focus on what has been referred to as consumptive value (Martin and Jefferies 1966; Smith and Martin 1972; Pope 1985), owner self-consumption (Campos and Caparrós 2006), or amenity value (used by us hereafter) as an important component for explaining unpriced woodland returns to landowners from the woodlands of Spain (dehesa), Portugal (montado), and California (ranch). This value represents amenities exclusively consumed by landowners as a form of nonmarket income from their land.

Landowners obtain commercial capital income from marketing commodities generated from their land investment (i.e., timber, meat), but they also seek amenities (i.e., landscape enjoyment, recreational opportunities, legacy values, rural lifestyle). Thus, landowners do not seem to be profitmaximizing commercially but to be utility-maximizing (Pope and Goodwin 1984), implying that they have mixed investorconsumer rationality. They give up or are willing to give up potentially higher commercial returns from alternative investments to consume amenity returns provided from their land investment. The difference in commercial net returns between the best potential alternative investment that they would forgo, and their land investment, is the maximum price that they are willing to pay for exclusive consumption of land amenities.

We posit that this willingness to pay (WTP) explains part of the economic value of the unpriced woodland returns accrued by landowners. We refer to this landowner-stated WTP private amenity value as an income value because we assume that this benefit is a joint output with commercial ones and that all the landowner's costs from land operations are exclusively associated with commercial activities because these are the main activities for which the costs occur. For this reason, the amenity output and income values are the same.

The Conventional System of National Accounts (SNA; InterSecretariat Working Group on National Accounts 1993), Farm Accountancy Data Network (European Commission 1999), and Cost and Return (American Agricultural Economics Association 2000) approaches measure direct-market payments to labor and capital production factors as the only income supplied by an economic activity. This conventional approach for income must be extended to include any nonmarket, scarce goods or services consumed or saved (net investment) by private landowners, public managers, and society within an accounting period (Hicks 1946; Eisner 1989; Food and Agriculture Organization 1998; Nordhaus and Kokkelenberg 1999). The nonmarket private amenity income, as it is defined above, is the value imputed to amenity returns consumed by the landowner within an accounting period (Campos and Caparrós 2006).

\section{Valuing Private-Amenity Values}

Previous work has evaluated private amenity values from the perspective of land price. Martin and Jefferies (1966) analyzed ranch sales in Arizona, concluding that consumption-related outputs explain high ranch prices. Pope (1985) examined data based on actual market transactions pertaining to average market value and average net returns of agricultural land in Texas. His main conclusion was that the land is purchased partly as a consumptive good and that this consumptive demand is a major determinant of land values. Standiford and Howitt (1992) applied a bioeconomic model to the oak woodlands of California, obtaining a firewood net-revenue function from market data and a hedonic pricing function from the actual behavior of landowners. The difference between these functions represents the value of oak trees to the landowner that is not explained by the wood or other commodities. Bastian et al. (2002) analyzed a hedonic function using a geographic information system for agricultural land prices in Wyoming. They found that demand for "remote" agricultural lands meant they had higher prices than other lands, irrespective of their relative capacity for agricultural production. Torell et al. (2005) applied a hedonic model to ranch sales in New Mexico, finding high values placed on desirable ranch location and recreational opportunities and that ranch income-earning potential explains a relatively small proportion of ranch-value variation.

The hedonic approach is useful when the main interest is the amenity component of land price, but it has limited interest if land transactions are rare or not transparent, as is partly the case in our study. Moreover, if the main interest is landowner-amenity income, as is also the case in our study, hedonic pricing has shortcomings because it only obtains the amenity land value. We can always link this value with the amenity income assuming an amenity discount rate but giving a precise value for this discount rate is far from obvious, and the income figure obtained would be highly dependent on the chosen discount rate.

Other authors have analyzed amenity values using alternative approaches. Campos and Riera (1996) and Raunikar and 
Table 1. Contingent valuation question used to assess respondents' personal values of their land: "How much do you estimate the current market value of your land to be without buildings or other infrastructures? How important are each of the following to your personal value for your property? Express each as a percentage of the total value, so that the percentages total $100 \%$ at the bottom."

\begin{tabular}{ll}
\hline \multicolumn{1}{c}{ Benefits } & Proportion of value to me \\
\hline Cork: & \\
Timber: & \\
Livestock: & \\
Hunting: & \\
Enjoyment of the countryside/landscape: & \\
Having friends and relatives visit: & \\
Others (please specify): & \\
TOTAL: & \\
\hline
\end{tabular}

Boungiorno (2006) employed an opportunity cost analysis of woodland and forest investments. Samuel and Thomas (1999) and Kallio (1999) used direct interviews with landowners to obtain, respectively, the land market value of unpriced forest products and the nonmarket component of the forest owners' utility function. Many other studies have found ample evidence of the importance of amenity values in ranching in the United States (Smith and Martin 1972; Workman 1986; Bartlett et al. 1989; Huntsinger et al. 1997; Starrs 1998; Gentner and Tanaka 2002).

This project attempts a direct measure of private amenity values as income from woodlands using contingent valuation (CV). This measurement can help fill the gap between theory and practice in calculating woodland total income for SNA. Current applications of SNA only include commodity components, but it is recognized even in official documents that the total return needed to explain land price includes amenities and that amenity value should be measured as part of total income (Eurostat 2002).

We apply a CV design to estimate this amenity component of woodland total income and its corresponding capital value. Landowners state their maximum WTP for the annual enjoyment of their land amenities and the component of the price of their land explained by amenities. We applied this design in surveys of nonindustrial, private landowners in five case study areas: the cork oak woodlands of Cádiz (southwest Spain), Gerona (northeast Spain), and the Alentejo coast (southwest Portugal); the mixed pine-oak woodlands of the Central and Ibérico systems (central range of Spain); and the oak woodlands of California (west coast of the United States). We estimate amenity-profitability rates for each case study and close with a discussion of the different land-simulated and amenity-simulated markets.

\section{METHODS}

\section{Design}

To estimate landowner amenity-income value, respondents were asked to consider a hypothetical situation in which they could earn more money by investing in an asset other than the land but of similar risks and time frame. In the initial situation (current) the landowner owns the land, obtains amenities (with a value of $A$ ), and gets commercial benefits (with a value of $C_{L}$ ) from the land asset. In the hypothetical (alternative) situation, the landowner sells the land and obtains benefits from investing in an alternative asset of similar risks and time frame but without amenity consumption. Thus, respondents are initially endowed with a higher level of amenities, and we ask the maximum amount of money that they are willing to pay (or give up as earnings) before moving to a better commercial investment with no amenity consumption. In this way, we are calculating the equivalent loss measure (Bateman et al. 2000). The wording of the question was

\footnotetext{
"Imagine that you could earn more money by investing in other assets (for example stocks or bonds) of comparable risk and time frame. How much is the maximum amounts of earnings you are willing to give up, per year, in this way, before selling your property to invest in an alternative that brings a higher return? (Keep in mind that by selling your estate your family and friends give up the exclusive right to enjoy the natural surroundings of your land, and you can no longer pass down this property to future beneficiaries)."
}

We chose to estimate the equivalent loss measure because it is more appropriate than a compensating gain measure in a context in which the respondents have the right to use the amenities. Another alternative would have been to use the compensating loss obtained from a willingness to accept question, but that kind of question generally offers upwardbiased results. We chose an open-ended question because of the higher efficiency of that format, important in some case studies due to the small size of the landowner target population.

For estimating the proportion of the land price explained by amenities, we asked landowners to state the market price of a hectare or acre of their woodland without considering buildings and infrastructure (with a value of $V_{L}$ ). Then, we asked them to allocate this price, as a percentage of the total, among the different active and passive uses of their property, based on how much they think each use contributes to this total price. The uses were specific to each case study, and they included amenity uses. The wording of the question is shown in Table 1.

These CV questions allow identification of landowner mixed investor-consumer rationality and measurement of amenity values as illustrated in Figure 1. In this figure, $N_{i}$ are woodland properties (ordered from more profitable to less profitable), $r_{C}$ is the commercial profitability part of the total profitability rate $\left(r_{T}\right)$, and $r_{A}$ is the amenity profitability part of $r_{T}$, that is, $r_{T}=r_{C}+r_{A}=C_{L} / V_{L}+A / V_{L}$. The CV questions yield the information necessary to obtain $r_{A}$.

We also asked landowners their motivations for keeping the land and whether they were currently forgoing the possibility of better commercial returns than the ones they were getting from their land investment (Fig. 2). That is, were they to the right $\left(n_{2}\right)$ or to the left $\left(n_{1}\right)$ of point B in Figure 1. In $n_{2}$, they are already paying for keeping their land, although their WTP could be higher. In $\mathrm{n}_{1}$, they are not paying, but they might be willing to pay if the situation should arise. In $\mathrm{n}_{3}$ (right of point D), $r_{T}$ is lower than the profitability of an alternative investment $\left(r_{I}\right.$ in Fig. 1), and the landowner is ready to sell the land. 


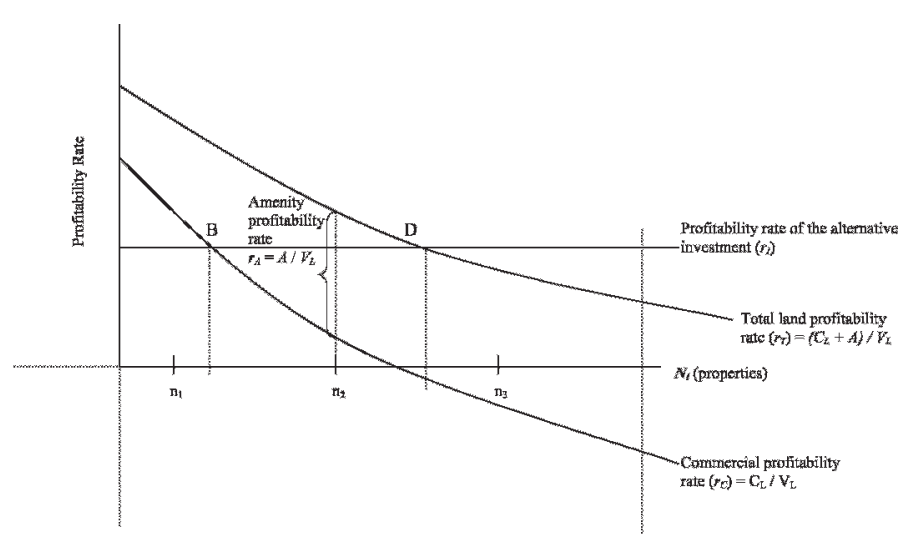

Figure 1. The mixed investor-consumer rationality hypothesis used in this evaluation includes the following components: $r_{A}$ indicates amenity profitability rate; $A$, amenity returns; $V_{L}$, land value; $r_{C}$, commercial profitability rate; $C_{L}$, commercial returns, $r_{T}$, total land profitability rate; $r_{l}$, profitability rate of the alternative investment; and $N_{i}$, properties. Landowners in $n_{1}$ are not incurring an opportunity cost; in point $B$,

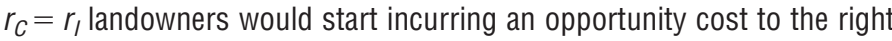
of this point. Landowners in $n_{2}$ are already incurring an opportunity cost for keeping their land; in point $D, r_{T}=r_{\text {, }}$ the landowner would be ready to sell their land to the right of this point. Landowners in $n_{3}$ would sell their land.

Situation $\mathrm{n}_{1}$ (Fig. 1) generates extraordinary commercial profitability rates $\left(r_{C}\right)$ for the landowner. Were these extraordinary commercial returns associated with the land asset, they would be incorporated in the land price as the value of expected, discounted net returns, and the extraordinary profitability would disappear. However, the extraordinary profitability persists for those in $\mathrm{n}_{1}$. Following Young (2005), what is likely to be happening here is that, for these landowners, there is unique managerial or production knowhow that creates a quasimonopolistic market. This results in extraordinary profitability that is not reflected in the land price. Thus, these extraordinary commercial returns are not capitalized in the land price but in the know-how of the landowner and/or land manager.

\section{Statistical Treatment}

WTP and land prices are presented in 2002 Euros per hectare. Data were updated using the consumer price and land price index variations for each corresponding country (Ministerio de Agricultura y Pesca 2005; Instituto Nacional de Estatística 2007; US Department of Agriculture 2007; US Department of Labor 2007). Dollars were converted to Euros using the 2002 official exchange rate $\$ 1.00=€ 1.06$ (The World Bank 2006), and acres were converted to hectares in the California case.

The mean and standard deviation of the WTP and land prices, as well as the land price allocation by use, have been weighted by property size. We do this because property size affects these values, and the weighted mean is a more appropriate measure of the total values of the total sampled land. "The land is not for sale" or "I will never sell my property" were identified as protest responses to the WTP question and were removed from the sample. Protest bids in CV generally reflect either a rejection of the hypothetical scenario or an inability to provide a value. This does not mean that the

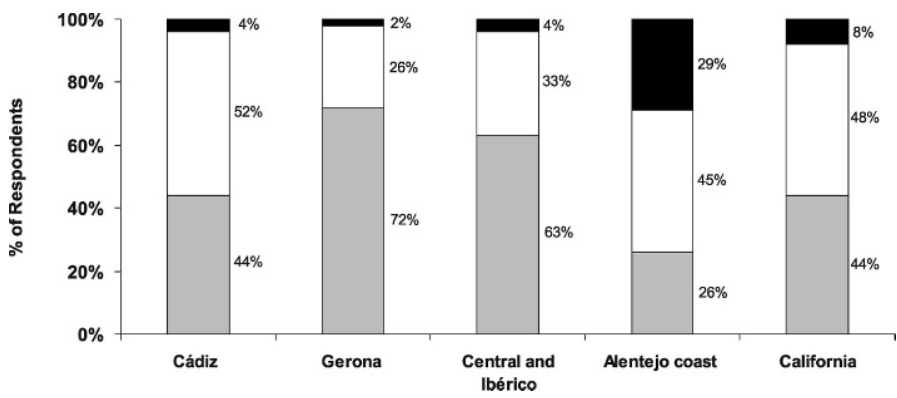

Figure 2. Do you think that you would make a better return on your investment by selling your land and investing in other assets with comparable time frames and risk (houses, bonds, etc.)? $\mathbf{n}$ No, annual cash-earning from my land is more profitable than other investments with comparable time frames and risk; $\square$ No, the value of my land will increase over time; $\square$ Yes, even when considering escalating land prices over time.

good being valued is priceless, but that it is not possible to obtain a value for it. Removing protest bids from the sample, we assume that the WTP for protest respondents is equal to the sample average WTP.

We use the models $W T P_{i}=\sum_{j=1}^{j} \beta_{j} X_{i j}+\varepsilon_{i j}$ and $L P R I_{i}=$ $\sum_{j=1}^{J} \beta_{j} X_{i j}+\varepsilon_{i j}$ to analyze the WTP and the stated land price, where $W T P_{i}$ is the individual's $i$ willingness to pay, and $L P R I_{i}$ is the individual's $i$ stated land price, $\beta_{j}$ is the coefficient corresponding to each explanatory variable $j, X_{i j}$ is the value for the explanatory variable $j$ for the individual $i$, and $\varepsilon_{i j}$ is the random error. We use linear (WTP-lin and LPRI-lin models) and semilog (WTP-slog and LPRI-slog models) specifications for these models. We selected these functional forms because they outperform more complex forms when the true explanatory variables are not known and proxy variables are used (Cropper et al. 1988), as it is the case here. For the regressions, we perform the Breusch-Pagan test, and if we reject the null hypothesis of absence of heteroskedasticity, we use White's heteroskedasticity consistent estimator of the variance-covariance matrix. Otherwise, we make a regular regression. Among other variables (see Results section), we include the property size as a regressor to capture the mentioned effect of the property size. This variable is retained in the model when significant. Regressions were run using the software NLOGIT version 9.0 (Greene 2007).

\section{Case Studies}

Four out of five cases $(80 \%)$ were conducted using mail surveys, whereas the remaining one (Alentejo coast, Portugal) used face-to-face interviews. In Central and Ibérico, Spain, $50 \%$ of the interviews were face to face because these landowners were difficult to reach by mail. In Cádiz, Spain, $45 \%$ of the interviews were also face to face because an attempted mail survey got very low responses. The survey procedures chosen responded, in each case, to the singularities of the landowner population.

Samples were randomly selected from data sets provided by public and private institutions in each study area (there were no official data available). The selection in California used a grid overlay that provided random point observations, with each 
Table 2. Socioeconomic characteristics of the landowners, and management and physical characteristics of their properties, from the five case study samples.

\begin{tabular}{|c|c|c|c|c|c|c|}
\hline \multirow[b]{2}{*}{ Variable } & \multirow[b]{2}{*}{ Definition } & \multicolumn{3}{|c|}{ Spain } & \multirow[b]{2}{*}{$\begin{array}{c}\text { Alentejo coast, } \\
\text { Portugal Mean } \\
\text { (SE) }\end{array}$} & \multirow[b]{2}{*}{$\begin{array}{c}\text { California Mean } \\
\text { (SE) }\end{array}$} \\
\hline & & $\begin{array}{l}\text { Cádiz Mean } \\
\text { (SE) }\end{array}$ & $\begin{array}{l}\text { Gerona Mean } \\
\text { (SE) }\end{array}$ & $\begin{array}{l}\text { Central and } \\
\text { Ibérico Mean } \\
\text { (SE) }\end{array}$ & & \\
\hline$S I Z$ & Property size (ha) & $710(602)$ & $140(194)$ & $493(470)$ & $114(155)$ & $2615(10992)$ \\
\hline TREE & Hectares of the property covered by trees & $452(450)$ & $129(182)$ & $246(260)$ & $87(94)$ & $1158(7170)$ \\
\hline LIV & $1=$ livestock grazing on the property $^{1}$ & $0.81(0.40)$ & $0.26(0.44)$ & $0.83(0.38)$ & $0.72(0.45)$ & $0.70(0.46)$ \\
\hline$B G S$ & $1=$ property has big game species $^{1}$ & $0.83(0.38)$ & $0.85(0.36)$ & $1.00(0.00)$ & $0.34(0.48)$ & $1.00(0.00)$ \\
\hline$B G$ & $1=$ private landowner hunting consumption $^{1}$ & $0.39(0.49)$ & $0.02(0.13)$ & $0.25(0.44)$ & $0.34(0.48)$ & $0.38(0.49)$ \\
\hline RES & $1=$ property has residential house ${ }^{1}$ & $0.74(0.44)$ & $0.65(0.48)$ & $0.40(0.50)$ & $0.51(0.51)$ & $0.77(0.42)$ \\
\hline PRO & $1=$ protective regulations affect the land $^{1}$ & $0.88(0.33)$ & $0.51(0.50)$ & $0.34(0.47)$ & $0.00(0.00)$ & $0.06(0.24)$ \\
\hline$A G E$ & Landowner's age (yr) & $51(11)$ & $56(10)$ & $53(11)$ & $58(7)$ & $61(13)$ \\
\hline GEN & $1=$ landowner is female ${ }^{1}$ & $0.07(0.25)$ & $0.04(0.19)$ & $0.15(0.36)$ & $0.14(0.35)$ & $0.17(0.38)$ \\
\hline WRK & $1=$ landowner works on the property $^{1}$ & $0.33(0.47)$ & $0.44(0.50)$ & $0.75(0.44)$ & $0.42(0.50)$ & $0.43(0.50)$ \\
\hline INC & Property contribution to family cash income (\%) & $34(34)$ & $19(20)$ & $15(17)$ & $49(25)$ & $50(44)$ \\
\hline VIS & $1=$ presence of the landowner on the property ${ }^{2}$ & $177(132)$ & $181(132)$ & $146(177)$ & $230(149)$ & $0.54(0.50)$ \\
\hline
\end{tabular}

${ }^{1}$ Otherwise takes a value of zero.

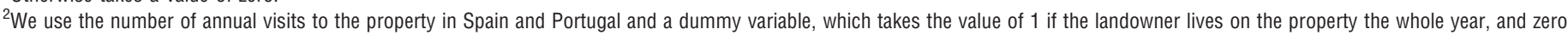
otherwise, in California.

one corresponding to a different property (redundancies were removed and the sample is weighted to larger ownerships by the grid method).

Survey response rate (percentage) and final sample size $(N)$ was, respectively, $35 \%$ and 64 landowners in Cádiz, Spain; $37 \%$ and 55 landowners in Gerona, Spain; 91\% and 52 landowners in Central and Ibérico, Spain; $100 \%$ and 50 landowners in the Alentejo coast, Portugal; and 52\% and 115 landowners in California. In Cádiz, Spain, we did the survey between 2002 and 2004; in Gerona and Central and Ibérico, Spain, in 2002; in the Alentejo coast, Portugal, in 2003; and in California in 2004.

Study Sites. The Cádiz study site was located in the 168000 ha Alcornocales Natural Park in southwest Spain, with corkoak (Quercus suber L.) woodland covering about $50 \%$ of the area. The Gerona study site was located in the Gerona province in northeast Spain and included 41000 ha of cork-oak woodlands. The Central and Ibérico study areas comprised the Scotch pine (Pinus silvestris L.) and oak (Quercus pyrenaica Willd.) woodlands located above $1000 \mathrm{~m}$ of elevation in the central range of Spain. The Alentejo coast site was located in Santiago do Cacem and Serra de Grandola shires in southwest Portugal and covered 58000 ha of cork-oak woodlands. The California site included oak (Quercus douglasii Hook. \& Arn., Quercus agrifolia Née, Quercus L. spp.) woodland ranches extending over 3 million ha.

Ownership. The proportion of these woodlands owned by the sampled landowners is $42 \%$ in Cádiz, Spain; 19\% in Gerona, Spain; $10 \%$ in the Alentejo coast, Portugal; and $12 \%$ in California. In Central and Ibérico, Spain, our sample was limited to private properties located above $1000 \mathrm{~m}$ in elevation (where Scotch pines are present), and the sample included almost $100 \%$ of the target population. For useable responses, the sampling error (at 95\% confidence level) of the WTP and of the stated land price is $<30 \%$ in all cases (Mitchell and Carson
1989), except for the California WTP (80\%) and land price $(71 \%)$ and the Central and Ibérico, Spain, WTP (49\%).

\section{RESULTS}

\section{Land and Property Characteristics}

The average property size in California is large, but there is high heterogeneity, as expected in a sample taken over such a big territory (Table 2). Cádiz and Central and Ibérico, Spain, are also of large average property size, but still a third of that of the California properties. The Gerona, Spain, and Alentejo coast, Portugal, samples are of small average size. In Gerona, Spain, smaller size is due to the advanced decline of woodland commercial activities in favor of primary or secondary residential houses, so large properties are disappearing. In Alentejo coast, Portugal, smaller size is due to a 19 th century process wherein church and nobility properties were divided up to create cereal croplands, leaving oak woodland parcels in the hands of small family-owned montados.

Livestock grazing is widely present in all cases but Gerona, Spain, whereas hunting of big game species is common in all cases, except in the Alentejo coast, Portugal (Table 2). Landowner hunting, as a private consumption activity, is important in California and Cádiz, Spain, but less so in Gerona, Spain, and Central and Ibérico, Spain. In Gerona, Spain, landowners have an implicit contract with local rural communities, providing de facto free access to local clubs for hunting on their properties. In the Alentejo coast, Portugal, case, commercial hunting activity is dominated by small game, and the existing big game is entirely used by the landowner (Table 2). Residential houses on the property are important in Cádiz and Gerona, Spain, and in California. Proximity to coastal villages in the Alentejo coast, Portugal, and the steep mountain highland area in Central and Ibérico, Spain, makes residential living on the property less common in these case studies (Table 2). 
Table 3. The response to several variables presented in the questionnaire that influence landowners' decision to retain their land (including an "other motivations" option), scored from 1 to 10 , with 1 indicating "no influence at all"; 10 , "strongly influenced"; $n$, total number of observations. Mean values are presented.

\begin{tabular}{|c|c|c|c|c|c|}
\hline \multirow[b]{2}{*}{ Motivations $^{1}$} & \multicolumn{3}{|c|}{ Spain } & \multirow{2}{*}{$\begin{array}{l}\text { Alentejo coast, } \\
\text { Portugal }(n=48)\end{array}$} & \multirow[b]{2}{*}{ California $^{2}(n=248)$} \\
\hline & Cádiz $(n=64)$ & Gerona $(n=54)$ & Central and Ibérico $(n=52)$ & & \\
\hline \multicolumn{6}{|l|}{ It is a commercially } \\
\hline profitable asset & 4.78 & 2.16 & 5.55 & 5.39 & 5.62 \\
\hline I enjoy the countryside & 7.45 & 6.95 & 6.44 & 0.88 & 8.27 \\
\hline \multicolumn{6}{|l|}{ It is a tradition and has } \\
\hline sentimental value & 3.63 & 7.43 & 6.78 & 4.62 & 9.17 \\
\hline \multicolumn{6}{|l|}{ I have always worked in } \\
\hline the countryside & 3.36 & 3.28 & 3.09 & 1.41 & 5.36 \\
\hline
\end{tabular}

${ }^{1}$ Although an "other motivations" option was presented, no one reached an average score higher than 1, and they are not shown.

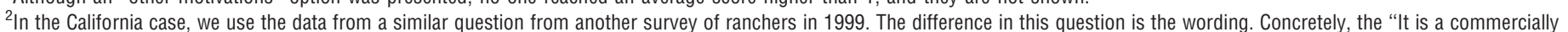

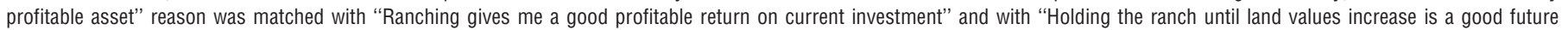

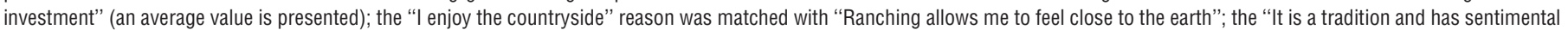

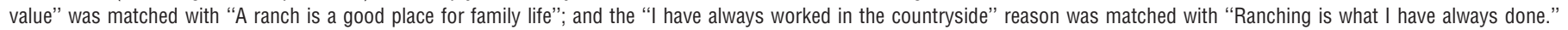

Regulations concerning protected natural areas affect the land significantly in Cádiz, Spain, but less in Gerona and Central and Ibérico, Spain. In the Alentejo coast, Portugal, no property is in a protected area. In California, protective regulation or zoning, which limits development of private lands, is relatively weak, with emerging stronger protections now coming through quasiprivate means, such as conservation easements. A conservation easement is a voluntary, legally binding agreement that limits certain uses or prevents development from taking place on a piece of land, implying payment to a private landowner to protect the ecological or open space values of the land. In the sample, $6 \%$ of the land was protected by easements (Table 2), although the easements are increasing rapidly in California (Land Trust Alliance 2006).

In all samples, the average landowner is middle-aged and mostly male. In Central and Ibérico, Spain, landowners work more on the property, whereas in the remaining cases, the percentage working the property is low. Property contribution to the landowner's family cash income is important in California; in the Alentejo coast, Portugal; and in Cádiz, Spain. In California, $>50 \%$ of the landowners in the sample live on the ranch year-round (Table 2). In Spain and Portugal, landowners usually do not live on the property, so we asked them the number of annual visits to the property (more than 140 annual visits on average in the four case studies).

\section{Private Amenity Values}

Table 3 shows how much different factors influenced landowner retention of properties, with 1 being "no influence at all” and 10 being "strongly influenced." In Cádiz, Spain, the main motivation was recreational, whereas in Gerona and Central and Ibérico, Spain, and California, motivation was sentimental. In the Alentejo coast, Portugal, commercial motivation (cash-earning plus land appreciation) scored highest, although sentimental motivation was also highly scored.

In response to the question about land-investment opportunity cost, we found that in all cases, except in the Alentejo coast, Portugal, only $>9 \%$ of landowners believed that annual cash earnings are enough to make the woodland a better investment (Fig. 2). Those who considered that land appreciation (in addition to cash earnings) was enough to make the woodland a better investment are greater in number in Cádiz $(52 \%)$, Spain; in California (48\%); and in the Alentejo coast, Portugal $(45 \%)$. Those who thought that they would earn more with other investments, even considering land appreciation, were $72 \%$ in Gerona, Spain; 63\% in Central and Ibérico, Spain; 44\% in Cádiz, Spain and California; and 26\% in the Alentejo coast, Portugal (Fig. 2).

Landowners in Gerona, Spain, reported the highest weighted mean WTP for amenity consumption, followed by Cádiz, Spain, and the Alentejo coast, Portugal (Table 4). Central and Ibérico, Spain, and California had the lowest ones. In all cases, WTP was higher than $€ 120 \cdot \mathrm{ha}^{-1}$. The highest stated land prices were found in California and in Cádiz, Spain $\left(>€ 8000 \cdot \mathrm{ha}^{-1}\right)$, and the lowest was in Gerona, Spain (slightly $>€ 3000 \cdot \mathrm{ha}^{-1}$ ). Central and Ibérico, Spain, and the Alentejo coast, Portugal, were in the midrange (around $€ 5000 \cdot$ ha $^{-1}$; Table 4).

In all cases, the amenity component represented $>30 \%$ of the land price. That amenity component was higher than the percentage of any of the single, commercial benefit in Cádiz and Central and Ibérico, Spain, and California. In Gerona, Spain, the total amenity percentage was close to that of cork, whose relative contribution to land price is high because of the small contribution of other commercial benefits. In the Alentejo coast, Portugal, cork and amenities explained most of the land price. In the decomposition of the amenity contribution to land price, the enjoyment of the landscape and sharing the property with relatives and friends were the most important in the Spanish cases. The heritage factor played the main role in the Alentejo coast, Portugal, and in California.

With this data, we can estimate the amenity profitability rate for each case study $\left(r_{A}\right.$ in Fig. 1), obtained by dividing the amenity income value $(A)$ by the stated land price $\left(V_{L}\right)$. The values for $r_{A}$ are 3\% in Cádiz, Spain; 7\% in Gerona, Spain; 3\% in Central and Ibérico, Spain; $4 \%$ in Alentejo coast, Portugal; and $2 \%$ in California. This $r_{A}$ is higher in the cases with smaller property size, meaning that landowners with larger properties retain more land to obtain similar levels of amenity income than do landowners with smaller properties, generating the lower amenity profitability for those large-property owners (a lower $A \cdot \mathrm{ha}^{-1}$ for the same $V_{L} \cdot \mathrm{ha}^{-1}$ ). This effect does not 
Table 4. Willingness to pay (WTP) values for private amenity consumption (weighted mean values are presented with standard errors shown in brackets), land price values stated by the surveyed landowners (weighted mean values are presented with standard errors shown in brackets) and results of the landowners' allocation of the stated land price by property use (weighted mean values are presented). Mean values have been weighted by property size. $n=$ number of observations.

\begin{tabular}{|c|c|c|c|c|c|c|c|c|c|c|}
\hline \multirow[b]{3}{*}{ Variable } & \multicolumn{6}{|c|}{ Spain } & \multirow{2}{*}{\multicolumn{2}{|c|}{$\begin{array}{l}\text { Alentejo coast, } \\
\text { Portugal }\end{array}$}} & \multirow{2}{*}{\multicolumn{2}{|c|}{ California }} \\
\hline & \multicolumn{2}{|l|}{ Cádiz } & \multicolumn{2}{|l|}{ Gerona } & \multicolumn{2}{|c|}{ Central and Ibérico } & & & & \\
\hline & Mean (SE) & $n$ & Mean (SE) & $n$ & Mean (SE) & $n$ & Mean (SE) & $n$ & Mean (SE) & $n$ \\
\hline WTP weighted mean $\left(2002 € \cdot\right.$ ha $\left.^{-1}\right)$ & $213(107)$ & 39 & $225(187)$ & 30 & $123(212)$ & 47 & $197(151)$ & 35 & $135(301)$ & 30 \\
\hline \multicolumn{11}{|l|}{ Stated land-price weighted mean } \\
\hline$\left(2002 € \cdot \mathrm{ha}^{-}\right)$ & 8451 (2 632) & 55 & $3068(1998)$ & 36 & 4828 (3 258) & 52 & $5474(1766)$ & 42 & 8878 (27 952) & 76 \\
\hline \multicolumn{11}{|l|}{ Allocation of the land market price by } \\
\hline use $(\%)$ & 100 & 58 & 100 & 44 & 100 & 52 & 100 & 50 & 100 & 101 \\
\hline Private commercial benefits (\%) & 64 & & 58 & & 69 & & 70 & & 43 & \\
\hline Cork $(\%)$ & 28 & & 44 & & - & & 52 & & - & \\
\hline Timber and forestry commodities (\%) & - & & 5 & & 21 & & - & & 10 & \\
\hline Livestock and pasture (\%) & 18 & & 3 & & 28 & & 17 & & 26 & \\
\hline Hunting $(\%)$ & 13 & & 4 & & 9 & & 1 & & 4 & \\
\hline Crops (\%) & 3 & & 2 & & 5 & & - & & 3 & \\
\hline Others $(\%)^{1}$ & 2 & & - & & 6 & & - & & - & \\
\hline Private amenity benefits (\%) & 36 & & 42 & & 31 & & 30 & & 57 & \\
\hline Landscape/countryside enjoyment (\%) & 20 & & 21 & & 3 & & 5 & & 13 & \\
\hline \multicolumn{11}{|l|}{ Enjoyment with relatives and friends } \\
\hline$(\%)$ & 10 & & 19 & & 26 & & 2 & & 10 & \\
\hline \multicolumn{11}{|l|}{ Animal (wildlife and livestock) } \\
\hline enjoyment $(\%)$ & 6 & & - & & - & & 1 & & - & \\
\hline Heritage value $(\%)$ & - & & 1 & & - & & 22 & & 24 & \\
\hline Conservation (\%) & - & & 1 & & 2 & & - & & 10 & \\
\hline
\end{tabular}

${ }^{1}$ Includes rural tourism, water, and long term investments.

appear with commercial profitability, because commercial incomes are provided in the same amount by each unit of land, even at higher levels because of economies of scale.

\section{Regression Analysis}

For the regression analysis, we use the variables from Table 2. Additionally, the WTP-lin and WTP-slog models included the stated land price $(L P R I)$, the log of stated land price $(L L P R I)$, and the amenity value of the stated land price (LPRIA); and the LPRI-lin and LPRI-slog models included the willingness to pay (WTP) and the log of willingness to pay $(L W T P)$. We also included quadratic terms for the continuous variables to test for nonlinear effects. We present the results of the preferred models, once correlated and nonsignificant $(<10 \%)$ variables were removed. We kept the variables that were significant, in at least in one of the specifications, to get the same model for the linear and the semilog specifications.

The regressions (using White's heteroskedasticity consistent estimator when we reject the hypothesis of no heteroskedasticity; see Breusch-Pagan test in Tables 5 and 6) were made separately for each case study because the selected models used a different set of explanatory variables in most of the cases (Tables 5 and 6) and restricting all case studies to the same regressors generated misspecified models. This suggests that, although they share some similarities, the amenitysimulated and land-simulated markets for each case study were different.
The regressions show that the WTP increases with the hectares of property covered by trees (TREE), with marginal decreasing increments (TREE $E^{2}$ is significant and negative) in Cádiz, Spain, and in the Alentejo coast, Portugal. In the latter case, the WTP decreased with the property size (SIZ), with marginal decreasing decrements $\left(S I Z^{2}\right.$ is significant and positive). In California, SIZ and TREE were correlated and could not be included in the same regression. When the regressions used TREE and TREE $E^{2}$ in the California case study in the semilog model (Table 5), we found an effect opposite to that found in Cádiz, Spain, and in the Alentejo coast, Portugal. When using $S I Z$ and $S I Z^{2}$ in the California case study in the semilog model, we obtained the same effects of $S I Z$ and $S I Z^{2}$ as in the Alentejo coast, Portugal (Fig. 3).

In all cases, the WTP increases with $L P R I$, except for Gerona, Spain, where we used the LPRIA to identify this effect. In Cádiz, Spain, and California, $L P R I^{2}$ was significant and negative. In Gerona and Central and Ibérico, Spain, WTP decreases with the landowner age $(A G E)$, with marginal decreasing decrements.

Alentejo coast, Portugal, was the case with the best goodness-of-fit, whereas Central and Ibérico, Spain, was the case with the worst one. In all cases, the linear models outperformed the semilog models.

In the analysis of the stated land price (per hectare; Table 6), we found that in Cádiz, Spain, the only significant variable was the presence of livestock on the property $(L I V)$, which had a positive effect. In all cases, except Cádiz, Spain, the WTP positively 


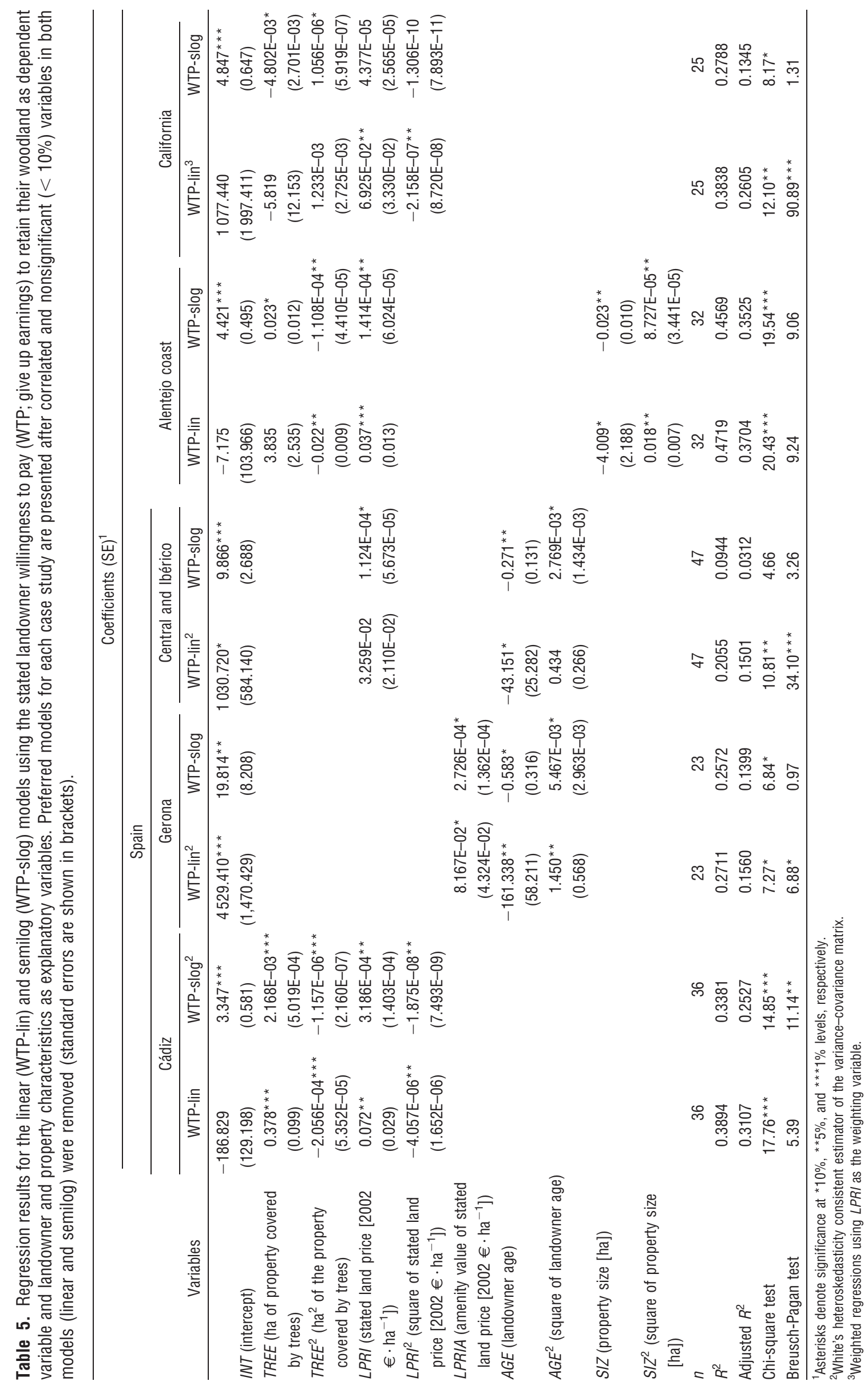




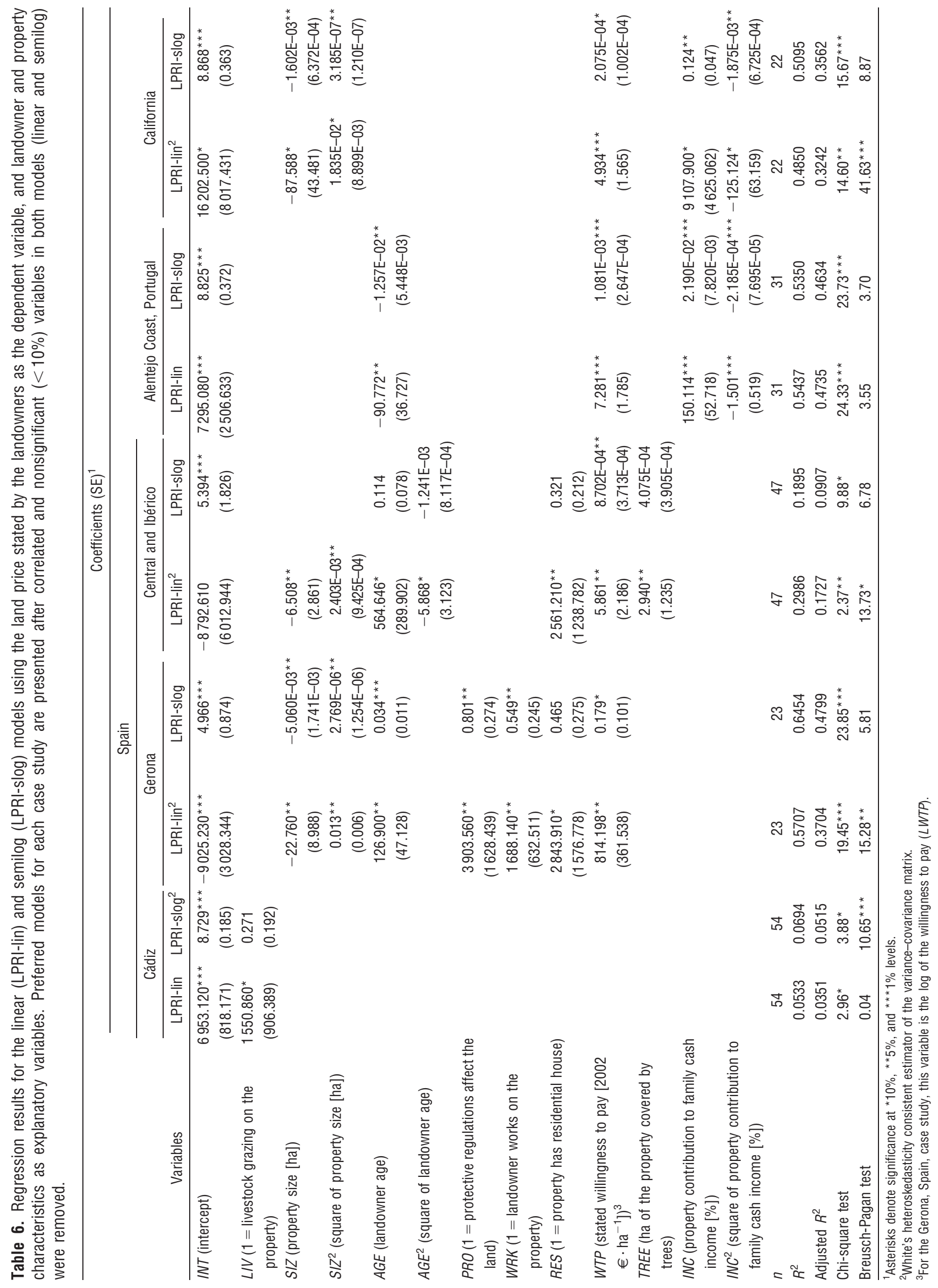




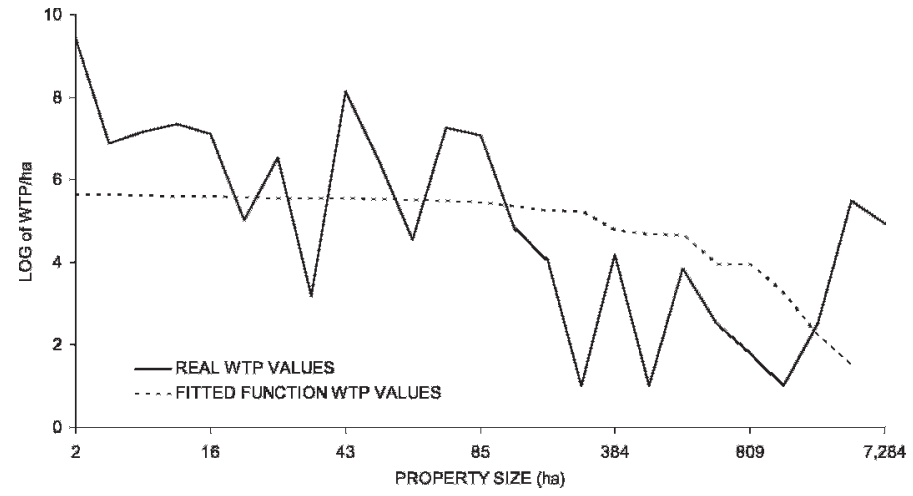

Figure 3. Saturation effect of property size on willingness to pay (WTP) for the California case study. The scale of the x-axis has been distorted (interval lengths between $\mathrm{x}$-axis values are not equal) to make it easier to perceive the saturation effect.

affected the stated land price, although in Gerona, Spain, we had to use the $\log$ of the WTP to find a significant effect.

In Gerona and Central and Ibérico, Spain, SIZ had a negative effect (with decreasing marginal decrements) and $A G E$ had a positive effect (with decreasing marginal increments only in Central and Ibérico, Spain) on the stated land price. We also found the former effect in California and the latter one in the Alentejo coast, Portugal, but with opposite sign. The percentage of the property contribution to the landowner family cash income $(I N C)$ increased the stated land price, with decreasing marginal increments in the Alentejo coast, Portugal, and in California. The presence of a residential house on the property (RES) showed a positive effect in Gerona and in Central and Ibérico, Spain. TREE had a positive effect in Central and Ibérico, Spain. Protective regulations affecting the land (PRO) and landowners working on the property (WRK) were significant only in Gerona, Spain.

Gerona, Spain; Alentejo coast, Portugal; and California had the best goodness-of-fit for these land price models, whereas Cádiz, Spain, had the worst one. There were mixed results about which model specification performed better, varying from case to case.

The regressions allowed simulation of the WTP for those landowners who did not answer the WTP question. Simulating the missing WTP values with semilog models because they reduce the possibility of the appearance of negative values and joining them with the real WTP values, we obtained a simulated weighted mean of $€ 201 \cdot \mathrm{ha}^{-1}$ for Cádiz, Spain; $€ 232 \cdot \mathrm{ha}^{-1}$ for Gerona, Spain; $€ 123 \cdot \mathrm{ha}^{-1}$ for Central and Ibérico, Spain; $€ 166 \cdot \mathrm{ha}^{-1}$ for Alentejo coast, Portugal; and $€ 41 \cdot \mathrm{ha}^{-1}$ for California. Most of these weighted means were smaller than the ones estimated with the actual answers. For the stated land price, we did not perform a simulation because we hardly recovered missing observations with the selected regression models.

\section{DISCUSSION}

The main contribution of this article is to the design and application of a CV survey aimed at estimating landowner amenity values (annual income and land price components) and verifying the landowner mixed investor-consumer rationality hypothesis in five Mediterranean woodland case studies.

Outside the Mediterranean woodlands, few studies have tried to value woodland private amenities. Raunikar and Buongiorno (2006) valued private amenities for the nonindustrial private owners of naturally regenerated, mixed-age, loblolly hardwood forests of the southcentral region of the United States. They used revealed preferences, on the basis of landowner willingness to incur a financial opportunity cost and assuming a 3\% real interest rate, to estimate an average lowerbound amenity income value of $\$ 149 \cdot \mathrm{ha}^{-1} \cdot \mathrm{yr}^{-1}$ at 1982 prices $\left(€ 249 \cdot \mathrm{ha}^{-1} \cdot \mathrm{yr}^{-1}\right.$ at 2002 prices). Samuel and Thomas (1999), assuming also a $3 \%$ real interest rate, estimated in 1995 that nonindustrial private-woodland owners in Wales might expect an upper-bound amenity income value with an interquartile range of $£ 13-67 \cdot \mathrm{ha}^{-1} \cdot \mathrm{yr}^{-1} \quad(€ 23-118$. $\mathrm{ha}^{-1} \cdot \mathrm{yr}^{-1}$ at 2002 prices). These values were measured through a stated-preference survey in which landowners were asked their WTP for their land considering its perceived priced and unpriced outputs. Kallio (1999) also used a statedpreference survey with nonindustrial, private forest owners in Finland to attribute the relative weights between the forest market profit (measured objectively on the basis of an income statement and balance sheets) and the amenity value perceived by the landowners. Starting from the market profit accounting data, the owner total-utility monetary value was measured, obtaining an upper-bound amenity income value range of $\mathrm{mk}$ 79 to $\mathrm{mk} 139$ (mk was the Finnish makkara) in 1994 per hectare per year $\left(€ 14-27 \cdot \mathrm{ha}^{-1} \cdot \mathrm{yr}^{-1}\right.$ at 2002 prices). All these values represent the amenity income as a range of $€ 14$ $294 \cdot \mathrm{ha}^{-1} \cdot \mathrm{yr}^{-1}$ at 2002 prices. The values estimated in our five Mediterranean woodlands case studies fall inside this range of values derived from the three studies described.

The CV method has not been used previously, to our knowledge, to value woodland private amenities and, given the shortcomings of hedonic pricing for that application (subjective discounting rates and the need for reliable data on land transactions), it appears to be a suitable alternative for the purpose. The estimation of amenity income using landowner WTP for private consumption of land amenities is especially important because, unlike with hedonic estimates, we obtained an objective measure that did not rely on the subjective decisions of the researcher. When the hedonic approach is applicable, however, our proposal for estimating the amenity component of the land price has no relevant advantages.

This estimation of WTP allows for constructing the landowner's aggregated amenity-demand function. Based on this function, we can estimate the exchange value of the amenity consumption (price times quantity), assuming how a virtual amenity market would work. The uniqueness of the woodlands in our case studies suggests that each landowner could demand the maximum WTP as a price and obtain the total amenity surplus value (the area under the demand function) as the amenity asset value incorporated in the land price when the land is sold. However, there is no definitive solution to this issue, and further research is needed.

The main policy implication of estimating this income value objectively is its inclusion in SNA as a total-exchange value for the measurement of woodland total income (Campos and Caparrós 2006). When policymaking is based on the informa- 
tion provided by SNA or by other official accounting systems based on SNA (Eurostat 2002), missing relevant values could lead to misguided decisions. Since the 1960s, agricultural economists have warned about the need to incorporate landowner amenity values in the economic analysis of woodland and ranching operations. In the words of Martin and Jefferies (1966): "There seems to be some problem of evaluation $[\ldots]$. Either the opportunity cost of capital is not recognized by ranchers or not all returns to ranching have been recognized in the analyses" (p. 234). We show that landowners recognize the opportunity cost of capital as well as the presence of noncommercial returns from their land operations.

In our applications of the CV design, the sample sizes and the number of useable responses are enough in most of the case studies but insufficient in some considering the target population. The reliability of the answers could raise some concerns about incentive compatibility because we used an open-ended format. However, the small target population in some cases offered problems for obtaining efficient estimates with discrete formats and made it difficult to do a pretest for designing a bid vector of the values to be offered. Apart from this, there is no reason to think that the landowner has incentive for not revealing true values.

The regressions reveal that the stated land price is positively associated with the WTP amenity income value. Another finding is that the hectares of property covered by trees in Cádiz, Spain, and in the Alentejo coast, Portugal, are positively related to WTP. In California, however, this effect is negative and can be seen as resulting from the positive effect of having grassland (the common alternative to tree-covered land in California). This effect is in accordance with ranching literature in the western United States, where amenity values are traditionally identified with a "cowboy lifestyle" (Starrs 1998), which requires large tracts of grassland on the property.

The regressions also show saturation in the amenity valuation related to property size in California, the case with the highest average property size, but also in the Alentejo coast, Portugal, where properties are relatively small. This effect implies that the marginal increments of the WTP decrease for large properties; that is, for two large properties the total WTP is very similar, but the WTP per hectare is lower in the larger property. This is reasonable because human perceptions are limited at very large scales and the same amenity enjoyment can be achieved in two properties with very large, but very different, sizes. A regression in the California case, using SIZ and $S I Z^{2}$ as regressors, shows this effect graphically (Fig. 3, see function). As can be seen, the WTP per hectare is similar for small properties, but it starts decreasing for properties larger than approximately 400 ha (Fig. 3).

This effect is closely related with that found in the analysis of amenity-profitability rates for each case study, which showed higher rates for cases with smaller properties. This could lead, or be leading, landowners to subdivide their properties and sell parcels if commercial operations disappear and amenity values remain as the exclusive motive for keeping the land, as partially happened in Gerona, Spain. Landowners can obtain significant amenity values from smaller parcels; they do not need larger properties unless they are also engaged in commercial production. This is a threat in terms of habitat fragmentation, especially in areas where legal restrictions are weak (i.e.,
California). Thus, although amenity values support woodland conservation because they help prevent land abandonment and urban conversion, commercial operations are also necessary to avoid habitat fragmentation and the loss of amenity values positively correlated with woodland working landscapes.

Other aspects should be considered to understand the context of each case study in which private amenities have been valued. California is the least-restrictive context for land conversion, where amenity values could be delaying the potential conversion. Conservation easements have an offset role here because the easement reduces the probability of land conversion, even when amenity values are not sufficient to prevent sale and development. An easement sale theoretically decreases the owner investment value in the land and, other things being equal, moves the $r_{C}$ and $r_{T}$ curves of Figure 1 to the right.

The easement value theoretically equals the commercial value of land development minus the commercial value of the current land use. However, in considering private amenity values, the easement value is likely to be lower because the difference between the commercial value of land development and the total value of the current land use (commercial plus amenities) is lower than the difference obtained considering only the commercial value of the current land use. Thus, the easement market could be influenced by these amenity values because landowners might be willing to accept lower easement prices because they too are obtaining benefits from avoiding land development.

Cádiz and Gerona, Spain, and the Alentejo Coast, Portugal, are cases close to coastal tourist destinations that increase the prestige of owing land, and they offer the highest WTP values. Most properties in Cádiz, Spain, are in a protected area, where legal restrictions decrease the probability of land conversion. Amenity values as well as commercial activities that are still predominant (cork, livestock, and hunting) can explain the high land prices. In Gerona, Spain, where only half of the sampled land is protected, the landownership structure is characterized by small properties for residential purposes. The potential process of subdivision is advanced here because commercial operations have gradually disappeared in recent decades. Only cork operations remain as an additional use to amenity consumption. This could explain high WTP and low land prices in this case study. In the Alentejo coast, Portugal, no land is protected and commercial activities are still competitive because of cork. We find a relatively high land price explained partly by amenities, partly by cork. In Central and Ibérico, Spain, properties are located in isolated mountain areas close to small villages, which could explain the lower WTP and land prices found.

\section{IMPLICATIONS}

Our case studies show that nonindustrial, private, Mediterranean woodland owners in the developed economies of Spain, California, and Portugal value and pay for the amenities of their properties. Most of them demonstrated a mixed investorconsumer rationality. Recreation and sentimental motivations encourage them to conserve and retain the land by assuming real or potential opportunity cost. They are willing to give up (pay) significant amounts of money annually to keep the land so as to enjoy its amenities, and they recognize that part of the 
land price of their property is explained by these amenities. The data analysis showed a positive significant association between the landowner WTP and the stated land price. We also found higher amenity profitability rates for cases with smaller average property size and a saturation effect in the WTP related to property size. All this has important implications in terms of subdivision and habitat fragmentation if commercial operations start disappearing, and amenities become the exclusive motivation for keeping the woodland.

Woodland owners, working to supply amenities for their own consumption, can produce public goods jointly with the ones they consume. This joint production of private amenities and public environmental services could reduce the amount of public and nonprofit funding needed for the provision of woodland public goods, including the preservation of wild habitats and endangered species, but it also justifies nonprofit and public investment in maintaining environmentally beneficial private stewardship. To some extent, this is already happening, even in the United States, where federal and local cost-sharing programs and nonprofit conservancies and land trusts support landowners who can demonstrate conservation objectives (Land Trust Alliance 2006; Environmental Defense Fund 2009). This finding, as reflected through the quantification of private amenity values in SNA, should encourage policymakers and conservation organizations to develop incentives to help private landowners incorporate the aim of increasing public goods into their management-and to help stabilize land uses that provide these benefits.

The CV design proposed in this article is a useful tool for estimating landowners' WTP for amenity consumption as an income amenity value to be included in SNA. This can help fill the gaps in applying the current SNA because it incorporates market commodities and unpriced amenity values, which have a corresponding asset value in the land market price. The use of $\mathrm{CV}$ avoids the data shortcomings and discounting assumptions of hedonic pricing. Although some uncertainty remains about the total exchange value to be used as woodland total income, our CV protocol ensures, at least, a first approximation. This approximation is better than continuing with the omission of unpriced woodland-amenity income in the operative application of SNA to rangelands around the world. Applying this finding in implementing national green-accounting statistics could improve the design of public policies, and it is crucial when high-value nature conservation is in the private domain.

\section{ACKNOWLEDGMENTS}

Authors wish to thank Paola Ovando, Institute for Public Goods and Policies (IPP) of the Spanish National Research Council (CSIC) in Spain, and Dr Adriana Sulak, Department of Environmental, Science, Policy and Management (ESPM), University of California, Berkeley (UCB), for assistance in data collection and statistical analysis. The usual disclaimer applies.

\section{LITERATURE CITED}

American Agricultural Economics Association. 2000. Commodity costs and returns estimation handbook. A report of the AAEA task force on commodity costs and returns. Ames, IA, USA: AAEA. $566 \mathrm{p}$.
Bartlett, E. T., R. G. Taylor, J. R. McKean, and J. G. Hof. 1989. Motivation of Colorado ranchers with federal grazing allotments. Journal of Range Management 42(6):454-457.

Bastian, C. T., D. M. McLeod, M. J. Germino, W. A. Reiners, and B. J. Blasco. 2002. Environmental amenities and agricultural land values: a hedonic model using geographic information systems data. Ecological Economics 40(3):337-349.

Bateman, I. J., I. H. Langford, A. Munro, C. Starmer, and R. Sugden. 2000. Estimating four hicksian welfare measures for a public good: a contingent valuation investigation. Land Economics 76(3):355-373.

Campos, P., and A. Caparrós. 2006. Social and private total Hicksian incomes of multiple use forests in Spain. Ecological Economics 57(4):545-557.

Campos, P., and P. Riera. 1996. Rentabilidad social de los bosques: análisis aplicado a las dehesas y los montados ibéricos. Información Comercial Española 751:47-62.

Cropper, M., L. Deck, and K. McConnell. 1988. On the choice of functional form for hedonic price functions. Review of Economics and Statistics 70(4):668-675.

EISNeR, R. 1989. The total incomes system of accounts. Chicago, IL, USA: The University of Chicago Press. $416 \mathrm{p}$.

Environmental Defense Fund. 2009. Environmental quality incentive programs. Available at: http://www.edf.org/page.cfm?taglD=3. Accessed 4 March 2009.

EURopean Commission. 1999. Farm accountancy data network (FADN). Available at: http://europa.eu.int/comm/agriculture/rica/index_en.cfm. Accessed 25 February 2009.

EURostat. 2002. The European framework for integrated environmental and economic accounting for forests-IEEAF. Luxembourg, Belgium: European Communities. $106 \mathrm{p}$.

Food and Agriculture Organization. 1998. Economic and environmental accounting for forestry: status and current efforts. Rome, Italy: Planning and Statistics Branch, Policy and Planning Division, Forestry Department, FAO. Available at: http://www.fao.org/docrep/005/AB600E/AB600E00.HTM. Accessed 25 February 2009.

Gentner, B. J., And J. A. Tanaka. 2002. Classifying federal public land grazing permittees. Journal of Range Management 55(1):2-11.

Greene, W. H. [computer program]. 2007. LIMDEP Version 9.0. New York, NY, USA: Econometric software, Inc.

HICKS, J. R. 1946. Value and capital. 2nd ed. Oxford, United Kingdom: Oxford University Press. $352 \mathrm{p}$.

Huntsinger, L., L. Buttolph, and P. Hopkinson. 1997. Ownership and management changes on California hardwood rangelands: 1985 to 1992. Journal of Range Management 50(4):423-429.

Instituto Nacional de Estadística. 2007. Indice de precios de consumo [Consumer price index]. Available at: http://www.ine.es/daco/ipc.htm and http://www.ine. pt/index_eng.htm [English version]. Accessed 25 March 2007.

Inter-Secretariat Working Group on National Accounts. 1993. System of National Account. Brussels, Luxemburg: Commission of the European Communities; Washington, DC, USA: International Monetary Fund; Paris, France: Organization of Economic Cooperation and Development; New York, NY, USA: United Nations; and Washington, DC: World Bank. 712 p.

KALLIO, T. 1999. Non-market benefits and forest owners' total utility in profitability calculations. In: C. S. Roper and A. Park [EDS.]. The living forest: non-market benefits of forestry. London, United Kingdom: Forestry Commission. p. 196-202.

Land Trust Alliance. 2006. 2005 National land trust census report. Washington, DC, USA: Land Trust Alliance. Available at: http://www.lta.org. Accessed 25 March 2007.

Martin, W. E., And G. L. Jefferies. 1966. Relating ranch prices and grazing permit values to ranch productivity. Journal of Farm Economics 48(2):233-242.

Ministerio de Agricultura y Pesca. 2005. Encuesta de precios de la tierra 2004. Available at: http://www.mapa.es/es/estadistica/pags/preciostierra/Precios_ tierra.htm. Accessed 20 July 2007.

Mitchell, R. C., and R. T. Carson. 1989. Using surveys to value public goods: the contingent valuation method. Washington, DC, USA: Resources for the Future. $463 \mathrm{p}$.

Nordhaus, W. D., and E. C. Kokkelenberg. 1999. Nature's numbers: expanding the national economic accounts to include the environment. Washington, DC, USA: National Academic Press. 250 p. 
Pope, C. A., III. 1985. Agricultural productive and consumptive use components of rural land values in Texas. American Journal of Agricultural Economics $67(1): 81-86$.

Pope, C. A., III. 1987. Agricultural productive and consumptive use components of rural land values in Texas: reply. American Journal of Agricultural Economics 69(1):179-181.

Pope, C. A., III, and H. L. Goodwin, JR. 1984. Impact of consumptive demand on rural land values. American Journal of Agricultural Economics 66(5):750-754.

RaunikAR, R., AND J. BuongioRno. 2006. Willingness to pay for forest amenities: the case of non-industrial owners in the south central United States. Ecological Economics 56(1):132-143.

Samuel, J., and T. Thomas. 1999. The valuation of unpriced forest products by private woodland owners in Wales. In: C. S. Roper and A. Park [eDs.]. The living forest: non-market benefits of forestry. London, United Kingdom: Forestry Commission. p. 203-212.

Smith, A. H., and W. E. Martin. 1972. Socioeconomic behavior of cattle ranchers, with implications for rural community development in the west. American Journal of Agricultural Economics 54(2):217-225.

Standiford, R. B., And R. E. HowitT. 1992. Solving empirical bioeconomic models: a rangeland management application. American Journal Agricultural Economics 74(2):421-433.
Starrs, P. F. 1998. Let the cowboy ride. Baltimore, MD, USA: John Hopkins University Press. $356 \mathrm{p}$.

The World Bank. 2006. World development indicators. Available at: http://devdata. worldbank.org/wdi2006/contents/toc.htm. Accessed 20 March 2007.

Torell, L. A., N. R. Rimbey, O. A. Ramírez, and D. W. McCollum. 2005. Income earning potential versus consumptive amenities in determining ranchland values. Journal of Agricultural and Resource Economics 30(3):537-560.

Torell, L. A., N. R. Rimbey, J. A. Tanaka, and S. Bailey. 2001. The lack of profit motive for ranching: implications for policy analysis. In: L. A. Torell, E. T. Bartlett, and R. Larrañaga [EDS.]. Proceedings of the Annual Meeting of the Society for Range Management; 17-23 February 2001; Kailua-Kona, HI, USA. Wheat Ridge, CO, USA: Society for Range Management. p. 47-58.

US Department of Agriculture. 2007. Economics, statistics, and market information systems. Available at: http://usda.mannlib.cornell.edu/. Accessed 25 March 2007.

US Department of Labor. 2007. Consumer price indexes. Available at: http://www. bls.gov/cpi/home.htm. Accessed 25 March 2007.

Workman, J. P. 1986. Range economics. New York, NY, USA: Macmillan Publishing. $217 \mathrm{p}$.

Young, R. A. 2005. Determining the economic value of water: concepts and methods. Washington, DC, USA: Resources for the Future. $374 \mathrm{p}$. 